\title{
PELATIHAN PEMBELAJARAN BERBASIS INTERNET BAGI GURU DI YAYASAN MUJAHIDIN KABUPATEN MALANG
}

Dr. Mohammad Maskan, M.Si, Achmad Suyono, S.Pd. MS, Drs. Bambang Soepeno, MM, Asminah Rachmi, S.E.,MBA, DBA

\begin{abstract}
Abstrak - Pembelajaran adalah proses transfer ilmu dari seorang guru kepada peserta didik. Untuk itu, maka metode pembelajaran yang digunakan harus sesuai perkembangan jaman sehingga menghasilkan lulusan yang memiliki keahlian sesuai dengan tuntutan jamannya. Terkait dengan hal tersebut, maka kegiatan Pengabdian kepada Masyarakat ini bertujuanuntuk memberikan pengetahuan kepada para guru tentang pembelajaran berbasis internet. Kegiatan Pengabdian kepada Masyarakat ini dilaksanakan pada Minggu 3 Nopember 2019 di Yayasan Mujahidin Kabupaten Malang. Kegiatan ini terbagi dalam beberapa tahap yang terdiri atas tahap persiapan, tahap pelatihan dan pembuatan laporan kegiatan.Tujuan diadakan pelatihan ini adalah agar para guru di Yayasan Mujahidin dapat memanfaatkan internet sebagai salah satu media dalam pembelajaran.Materi yang diberikan dalam pelatihan ini meliputi pengertian pembelajaran berbasis internet, ruang lingkup, keuntungan dan kerugian pembelajaran berbasis internet serta mempraktekkan proses pembelajaran berbasis internet.

Selama proses pelatihan situasinya terjalin secara edukatif, kondusif dan menyenangkan. Hal ini dapat terlihat dari antusias peserta, proses tanya jawab dan keikutsertaan peserta secara lengkap mulai awal sampai selesainya acara pelatihan sehingga materinya dapat selesai secara keseluruhan..
\end{abstract}

\section{Kata kunci: Pembelajaran, internet}

\section{PENDAHULUAN}

\subsection{Latar Belakang}

Menurut Degeng (2001:30) belajar adalah proses pemaknaan informasi baru. Sebab segala sesuatu bersifat temporer, berubah dan tidak menentu. Kitalah yang memberi makna terhadap realitas. Untuk itu, proses pembelajaran harus dapat menghasilkan sosok manusia yang mampu menggunakan pengetahuan secara bermakna, memperhatikan pola pandang si peserta didik, aktivitas belajar dalam konteks nyata dan menekankan pada proses. Dengan demikian, strategi pembelajaran yang sesuai dengan tuntutan milenium tersebut adalah strategi konstruktivistik, dimana dalam strategi ini memiliki karakteristik: penyusunan makna secara aktif, menuntut pemecahan ganda dan evaluasi merupakan bagian utuh dari pembelajaran. Oleh sebab itu, guru sebagai salah satu faktor eksternal yang penting dalam menentukan keberhasilan peserta didik harus berperan dengan baik dan memiliki kinerja yang baik. Menurut. Sahertian (1992), menjelaskan bahwa ciri guru yang memiliki kinerja yang baik adalah sebagai berikut: (1) guru dapat melayani pembelajaran peserta didik secara individual, (2) guru memberi persiapan dan perencanaan pembelajaran yang diperlukan, (3) guru mengikutsertakan peserta didik dalam berbagai pengalaman belajar, dan (4) guru menempatkan diri sebagai pemimpin yang aktif bagi peserta didik. Disamping itu, guru dituntut untuk selalu mengikuti perkembangan pengetahuan dan kompetensi pedagogiknya yang relevan dengan perkembangan jaman, dimana salah satunya adalah memanfaatkan kemajuan teknologi komunikasi dan informasi sebagai media pembelajaran. Bukan jamannya lagi, guru didalam proses pembelajaran hanya mengandalkan pendekatan klasikal tanpa melibatkan teknlogi informasi didalam pembelajarannya. Penggunaan buku elektronik, radio, film, TV, multi media interaktif dan internet merupakan media yang dapat meningkatkan kualitas pembelajaran dan hasilnya. Pembelajaran berbasis WEB Modular ini guru memberikan kebebasan dan keberagaman kepada mahasiswa. Kebebasan yang dimaksudkan di sini adalah kebebasan untuk melakukan pilihan-pilihan sesuai dengan apa yang mampu dan mau dilakukan mahasiswa. Sedangkan keberagaman yang dimaksud adalah mahasiswa menyadari bahwa individu berbeda dengan orang/kelompok lain dan orang/kelompok lain berbeda dengan individunya. Disamping itu, dalam pelaksanaan pembelajaran guru memandang mahasiswa sebagai pribadi yang sudah memiliki kemampuan awal sebelum mempelajari sesuatu. Kemampuan awal tersebut akan menjadi dasar dalam mengkonstruk pengetahuan yang baru. Mahasiswa juga akan berinteraksi dengan lingkungannya. Semakin sering mahasiswa berinteraksi maka akan semakin banyak pengalaman yang dimiliki yang berarti dasar pengetahuannya juga semakin banyak. Guru yang baik harus mampu memahami jalan pikiran siswa dan tidak memaksakan agar siswa mau mengikuti cara-cara yang diberikan guru. Sebagaimana yang dikatakan Dahar R.W. (1988) bahwa peran guru dalam proses belajar adalah membantu siswa dalam membentuk pengetahuannya sendiri. Glover, J.A. dan Bruning R.H (1990) menambahkan bahwa "the best teachers, of course, have many fine atributes in addition to teaching skills they know a great deal about students, they enjoy students, and they are knowledgeable and enthusiastic about their subject matter". Kemudian Orlich D.C. (1998) menambahkan bahwa "good teachers are able to develop student thinking, facilitate student development, 


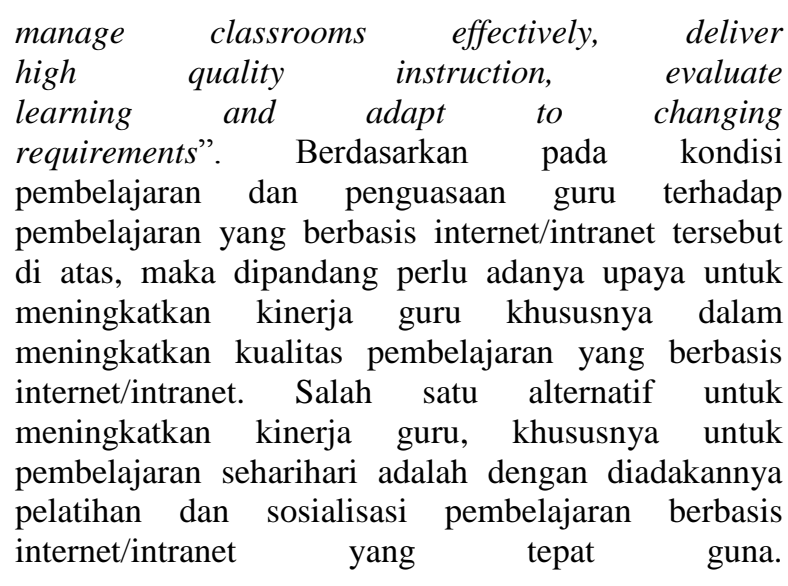

\section{TINJAUAN PUSTAKA}

Kajian Teoritik tentang Pembelajaran Berbasis Komputer Menurut Kulik dan Kulik (1978), pembelajaran berbasis/berbantuan komputer memiliki kelebihan sebagai berikut: Pertama, memberi kemudahan bagi tenaga pendidik untuk merancang dan memberikan kuis, latihan dan tugas (task) sebanyak yang diperlukan. Kedua, memberi kemudahan bagi tenaga pendidik merancang dan memberikan balikan (feedback) sesegera mungkin terhadap jawaban mahasiswa. Ketiga, memberi kemudahan bagi tenaga pendidik untuk merancang bentuk remediasi (remedial) bagi mahasiswa yang belum berhasil mencapai tingkat penguasaan yang telah ditetapkan. Peluang lebih besar bagi pembelajaran berbasis komputer untuk meningkatkan prestasi belajar juga dimungkinkan karena perkembangan mutakhir teknologi komputer memasuki abad-20 yang semakin terpadu dengan teknologi komunikasi, telekomunikasi dan audio-visual. Semula, komputer hanya dipakai untuk kegiatan berdiri sendiri (stand alone), tidak terpadu dalam sebuah jaringan (network). Kini, setelah komputer makin terpadu dengan berbagai bentuk media dan jaringan telekomunikasi, maka teknologi komputer memungkinkan para penggunanya (user) dalam waktu yang bersamaan namun tetap dalam kerangka pelaksanaan suatu pembelajaran yang bersifat individual (melayani individu mahasiswa). Fasilitas yang dimaksud dalam kaitan uraian di atas merujuk adanya perkembangan dalam jaringan global (global net) tanpa batas (dunia maya) yang didukung fasilitas jaringan internet dalam menciptakan dunia maya secara nyata lewat teknologi komunikasi dan teknologi komputer. Maka konsep yang muncul kemudian, bahwa pembelajaran yang dilaksanakan lewat pemanfaatan internet sebagai penghubung ke berbagai jaringan dan situs-situs dunia maya tersebut memungkinkan para pebelajar/mahasiswa dan juga pembelajar/guru/instruktur dapat dengan mudah melakukan interaksi lewat perangkat komputer yang berada di dekatnya, bebas waktu dan tempat, dimanapun para pengguna (user) sedang berada. Maka semakin nyatalah dimunculkannya konsep Pembelajaran Berbantuan Internet sebagai bagian penting dari konsep pembelajaran berbantuan komputer berbasis komputer . Pada perkembangan selanjutnya, maka konsep Pembelajaran Berbantuan Internet dengan menggunakan dan memanfaatkan jaringan internet tidak sekedar melaksanakan pembelajaran yang hanya menggunakan perangkat teknologi komputer secara berdiri sendiri, tetapi juga akan mengaplikasikan kemajuan-kemajuan dalam bidang teknologi telekomunikasi, teknologi digital, teknologi audio-visual, animasi dan cinematografi, serta teknologi pembelajaran itu sendiri, sehingga tercipta proses pembelajaran yang efektif (Stai \& Pohl, 1981 ). Secara empiris, sejumlah perguruan tinggi negeri maupun swasta di Indonesia telah pula berupaya menerapkan dan mengembangkannya ke arah penerapan teknologi komputer dan telekomunikasi secara canggih. Di beberapa perguruan tinggi, telah menggunakan fasilitas teknologi informasi, komunikasi dan komputer dalam bentuk jaringan internet, baik secara global (Global Area Network) maupun secara lokal (Local Area Network/LAN). Semua fasilitas tersebut diupayakan untuk diarahkan secara khusus agar dapat dimanfaatkan bagi kepentingan proses pendidikan atau proses pembelajaran bagi kepentingan perkuliahan bagi para mahasiswanya. Dari pengamatan di beberapa perguruan tinggi di Indonesia, misalnya: Universitas Brawijaya (UNIBRAW), Universitas Negeri Malang (UM), Universitas Merdeka Malang (UNMER), Universitas Muhammadiyah Malang (UMM), UIN dan STIMIK dapat terungkap bahwa walaupun sebenarnya sistem jaringan global yang menggunakan fasilitas internet dapat dimanfaatkan mahasiswa untuk melakukan kegiatan belajar setiap saat, ternyata pada umumnya pihak tenaga pendidik di perguruan tinggi tersebut belum memanfaatkan sistem jaringan tersebut secara optimal guna menyajikan materi perkuliahan, sedangkan di pihak mahasiswa juga belum memanfaatkan sistem jaringan tersebut secara maksimum sebagai suatu fasilitas pengayaan sumbersumber belajar. Pengamatan pada sejumlah perguruan tinggi di kota besar lainpun ternyata juga menunjukkan kenyataan yang sama. Artinya, belum banyak upaya untuk memetik manfaat sebesar mungkin dari kehadiran sistem jaringan Internet untuk kepentingan pelaksanaan proses pembelajaran/perkuliahan. Komputer dan internet sebagai jaringan global digunakan sebatas penyediaan informasi kelembagaan (situs kelembagaan) dan informasi perkuliahan, belum menyentuh langsung pada layanan proses pembelajaran. Di beberapa perguruan tinggi maju di Idonesia, misalnya Institut Teknologi Bandung, Universitas Brawijaya sudah dilaksanakan kerjasama dengan Jepang untuk menyelenggarakan program SOI (School of Internet), program ini sudah melakukan sistem pembelajaran dengan bantuan internet, dan sistem ini sering disebut e-learning (pembelajaran elektronik). Hanya saja penyusunan e-learning (pembelajaran elektronik) yang telah digunakan di perguruan tinggi negeri tersebut belum maksimum menggunakan kosep-konsep dan prinsip-prinsip desain pembelajaran, akan tetapi tujuan bantuan SOI ini adalah mengembangkan infrastruktur satelit di dunia pendidikan tinggi di Asia melalui teknologi digital dan internet, dengan memanfaatkan pendidikan jarak jauh 
serta teknologi yang dikembangkan oleh program SOI (Hidayat \& Fauzie, 2003). Sedangkan Uniersitas Terbuka dan Pustekom telah melaksanakan program pembelajaran e-learning (pembelajaran elektronik) dirancang menggunakan prinsip-prinsip desain pembelajaran ( Anwas, 2003). Pada kenyataannya, dunia pendidikan harus mempersiapkan SDM yang siap bersaing dalam era globalisasi (http://Teknologi.US), di mana fasilitas internet semestinya dapat digunakan pula untuk melakukan konsultasi masalah belajar mahasiswa, pemberian tugas, balikan, ujian dan remidiasi bagi mahasiswa, dan menciptakan kegiatan layanan secara interaktif antara guru dengan mahasiswa dan antara mahasiswa dengan mahasiswa dalam melakukan pengayaan bahan-bahan belajar bagi kepentingan perkuliahan. Dengan demikian fasilitas pembelajaran berbantuan internet dapat digunaka sebagai media pembelajaran yang efektif.

\subsection{Pengertian Website}

Website merupakan kumpulan dari semua halaman web yang terangkum dalam satu kesatuan

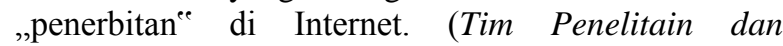
Pengembangan Wahana Komputer, 2002). Sedangkan definisi lain dari website adalah sebuah kumpulan halaman (webpages) yang diawali dengan halaman muka (homepages) yang berisikan informasi, iklan, serta program interaksi.( $A$ to $Z$ internet, 2003). Dari beberapa kutipan di atas dapat disimpulkan bahwa website adalah istilah penunjukan alamat internet yang berisikan kumpulan dari semua halaman web yang terangkum dalam satu kesatuan yang dapat dijadikan media untuk penyampaian informasi baik untuk perorangan maupun organisasi atau perusahaan.

Fungsi Website. Fungsi website pada suatu organisasi yang ada di internet bagi organisasi itu sendiri adalah sebagai berikut

d. Sarana Informasi Dengan adanya website, maka perusahaan atau organisasi bisa menyajikan suatu informasi kepada para konsumennya ataupun kepada masyarakat luas. Informasi yag disampaikan melalui website ini misalnya: profil perguruan tinggi, jasa yang diwarkan dan lain sebagainya. e. Sarana Promosi Dengan memiliki website, maka organisasi bisa lebih mudah mempromosikan produk atau jasa terbaru mereka dengan tampilan yang lengkap dan menarik karena dilengkapi dengan fotofoto, spesifikasi, dan keunggulan dari produk atau jasa yang

$\begin{array}{llr}\text { f. Sarana } & \begin{array}{c}\text { meningkatkan } \\ \text { kepada }\end{array} & \begin{array}{r}\text { mutu } \\ \text { konsumen. }\end{array}\end{array}$

Website yang dimiliki oleh suatu organisasi sangat besar kontribusinya dalam meningkatkan pelayanan kepada para konsumennya, karena melalui website tersebut konsumen bisa mengirimkan saran komentar dan bisa juga melakukan pemesanan tentang produk atau jasanya. Jaringan global internet yang bersifat tanpa batas pada dasarnya adalah suatu wadah dan wahana bagi siapapun untuk dapat masuk dan terlibat secara interaktif di dalam dunia maya tanpa dibatasi ruang dan waktu, serta terkait dengan unsur ruang, waktu, tempat, dan usia. Perkembangan aplikasi teknologi informasi di dunia pendidikan, memacu munculnya kegiatan rancangan pembelajaran berbantuan internet baik secara synchronous maupun asynchronous. Synchronous artinya bahwa pengajar/guru dan mahasiswa berinteraksi secara waktu nyata (real time), beberapa peralatan yang menggunakan cara ini relative mahal. Misalnya dengan two-way videoconfrences, audioconferencing, internet chat, dan desktop video conferencing. Penyampaian materi dengan asynchronous tidak secara bersamaan, pengajar/guru menyampaikan instruksi melalui video, computer atau lainnya, dan mahasiswa merespons pada lain waktu. Misalnya instruksi disampaikan melalui web atau dan feedback disampaikan melalui e-mail (Koswara, E, 2003, Soekartawi, 2003). Salah satu kegiatan rancangan pembelajaran berbantuan internet adalah penggunaan nya untuk penyampaian materi perkuliahan saat guru dan mahasiswa dipisahkan oleh jarak sehingga tidak terjadi komunikasi tatap muka langsung. Teknologi suara, video, data dan cetakan digunakan sebagai jembatan antara guru dan mahasiswa untuk menyampaikan dan mendiskusikan bahan pelajarannya. Konsep program rancangan pembelajaran berbantuan internet menyediakan kemudahan bagi siapa saja yang berminat belajar, yang mempunyai keterbatasan waktu, keterbatasan jarak , cacat fisik, para pekerja di perusahaan yang ingin meningkatkan poengetahuannya tanpa harus meninggalkan pekerjaannya. Faktor-faktor pendukung untuk mewujudkan pengembangan software pembelajaran berbantuan internet ini, yaitu (1) adanya kebutuhan mahasiswa untuk meningkatkan hasil belajar, (2) ketertarikan mahasiswa dan guru terhadap pembelajaran berbantuan internet, (3) tingginya minat guru dan mahasiswa untuk memanfaatkan hasil pengembangan software pembelajaran (4) tersedianya perangkat fasilitas yang memadai, dan (5) belum tersedianya

software pembelajaran berbantuan internet yang dikembangkan secara khusus. Teknologi internet pada hakekatnya merupakan perkembangan dari teknologi komunikasi generasi sebelumnya yang memiliki sifat interaktif, bisa sebagai media massa dan internasional dan sumber informasi dari berbagai penjuru dunia sangat memngkinkan menjadi media pendidikan lebih unggul dari generasi sebelumnya. Oleh karena itu, Tung (2000) menyatakan bahwa setelah kehadiran pengajar dalam arti sebenarnya, internet akan menjadi suplemen dan komplemen dalam mewujudkan wakil pengajar yang mewakili sumber belajar yang penting di dunia. Sejalan dengan hal tersebut, Purbo (1998) menyatakan bahwa paling tidak ada tiga hal dampak positip penggunaan internet dalam pendidikan, yaitu: a) Mahasiswa dapat dengan mudah mengambil mata kuliah dimanapun di seluruh dunia tanpa batas institusi ataupun Negara, b) Mahasiswa dapat dengan mudah berguru pada para ahli di bidang yang diminatinya dan c) Kuliah/belajar dapat dengan mudah diambil di berbagai penjuru dunia tanpa bergantung pada 
universitas/sekolah mahasiswa belajar. Disamping itu, kini hadir perpustakaan internet yang lebih dinamis dan bisa digunakan di seluruh jagad raya. Lebih lanjut Raharjo (2002) menyatakan bahwa manfaat internet bagi pendidikan adalah dapat menjadi: a) akses kepada sumber informasi, b) akses kepada nara sumber dan c) sebagai media kerjasama. Akses kepada sumber informasi yaitu sebagai perpustakaan on-line, sumber literature, akses hasil-hasil penelitian dan akses kepada materi pembelajaran. Komunikasi kepada narasumber bisa dilakukan tanpa harus bertemu secara fisik. Sedangkan sebagai media kerjasama, internet bisa menjadi media untuk melakukan penelitian bersama atau membuat semacam makalah bersama. Dalam era new economy mendatang, menurut Patmanthara (2004) berbagai lembaga pendidikan dari berbagai tingkatan skala, segala kiprahnya akan memanfaatkan internet sebagai tumpuan pengembangannya. Berdasarkan skalanya, Oetomo (2002) lembaga-lembaga pendidikan tersebut dapat dikelompokkan sebagai berikut: 4) Lembaga produsen produkproduk teknologi, yaitu lembaga pendidikan yang beroperasi di beberapa negara seperti Cisco, Oracle, Microsoft dan Autodesk. Lembaga-lembaga ini mengetengahkan internet pendidikan untuk memberikan fasilitas pendidikan atau konsultasi bagi pemakai produkproduknya. 5) Lembaga pendidikan menengah dan tinggi, yaitu lembaga pendidikan menengah dan tinggi yang tersebar di berbagai belahan dunia yang menawarkan sistem dan materi pendidikan yang secara unik disusunnya kepada para calon mahasiswa di berbagai pelosok dunia. 6) Lembaga pendidikan nonkurikuler, yaitu lembagalembaga pendidikan yang menyelenggarakan kursus jarak jauh bagi peserta didiknya. Hasil-hasil penelitian empiris yang terkait dengan pembelajaran berbantuan internet nampaknya menunjukkan adanya dampak yang positif, baik bagi mahasiswa, proses pembelajaran dan pencapaian obyektif pembelajaran. Hasil penelitian Pavlik (1996) di Amerika Serikat tentang efektifitas pemanfaatan teknologi informasi dalam pendidikan menunjukkan bahwa pemanfaatan teknologi informasi dibandingkan teknologi instruksional lebih menguntungkan dalam hal penghematan waktu sebesar $30 \%$, menghemat biaya $30-40 \%$ dan lebih meningkatkan prestasi mahasiswa. Hasil penelitian ini diperkuat oleh studi yang dilakukan Center for Applied Special Technology (CAST) pada tahun 1996 (dalam Anwas, 2003), yang dilakukan terhadap sekiar 500 siswa kelas lima dan enam sekolah dasar. Jumlah siswa ini dibagi dalam dua kelompok, yaitu kelompok eksperimen yang kegiatan belajarnya dilengkapi dengan akses internet dan kelompok kontrol. Hasilnya, setelah dua bulan diketahui bahwa kelompok eksperimen mendapat nilai yang lebih tinggi berdasarkan tes akhir. Demikian juga penelitian yang dilakukan oleh Nuraini (2003) yang dilakukan pada mahasiswa ITB tahun pertama, dalam mata kuliah kalkulus, proses perkuliahan yang ditunjang dengan modul multimedia, CD materi pengajaran dan Website. Hasil penelitian menunjukkan bahwa semangat belajar mahasiswa terlihat meningkat cukup signifikan bila metode pembelajaran disajikan dalam bentuk multi media sehingga dapat mencapai hasil belajar yang tinggi. Oleh karena itu, Saepudin (2003) menyatakan bahwa penyelenggaraan pendidikan nasional bagi masyarakat yang bersifat konvensional, mengalami banyak kendala ketika dituntut untuk memberikan pelayanannya bagi masyarakat luas yang tersebar di seluruh Indonesia. Kendala tersebut diantaranya selain keterbatasan finansial, jauhnya lokasi dan keterbatasan jumlah institusi. Sementara, saat ini telah berkembang pembelajaran internet yang dapat dimanfaatkan untuk mengatasi kendala tersebut. Untuk itu, sudah saatnya pembelajaran internet dimanfaatkan secara optimal dalam penyelengaraan pendidikan di Indonesia, khususnya terkait dengan masa depan pendidikan Indonesia yang akan menghadapi persaingan global yang sangat ketat.

\subsection{Tolok Ukur Keefektifan Pembelajaran}

Telah dikemukakan, dalam beberapa dasawarsa belakangan ini, banyak penelitian eksperimen dilakukan untuk mengetahui apakah kedudukan pembelajar (The Teacher) dapat digantikan oleh masukan piranti yang lain, khususnya media atau teknologi pembelajaran. Namun demikian, sebagaimana dikaji-ulang oleh Kulik dan Kulik (1978: 71 -78), bahwa meskipun beberapa media atau teknologi pembelajaran dapat meningkatkan prestasi belajar mahasiswa meskipun hasilnya juga belum menampakkan keajekan, ternyata belum bisa secara memadai menggantikan peranan dan kehadiran pembelajar. Ini sekaligus menunjukkan bahwa peranan dan kehadiran pembelajar yang menyelenggarakan pembelajaran langsung (direct instruction) memiliki arti bagi proses pembelajaran. Medley (1978: 11) mengemukakan bahwa pengaruh persekolahan terhadap individu mahasiswa bergantung pada siapa pembelajarnya. Biaya personalia untuk pembelajar sendiri menunjukkan bahwa begitu banyak biaya keseharian pendidikan diarahkan pada peningkatan keefektifan pembelajarannya. Menurutnya, terdapat dua cara untuk meningkatkan keefektifan pembelajar. Pertama dengan memperbaiki cara-cara penilaian terdadap tenaga pendidik. Kedua melalui perubahan cara-cara tenaga pendidik dididik. Perjalanan penelitian mengenai keefktifan pembelajar mencerminkan suatu perubahan bertahap mengenai konsepsi peneliti terhadap sifat dasar keefektifan, yang sebagian besar ditentukan oleh sifat dasar poenelitian dan kemanfaatannya (Medley, 1978: 11 - 26). Pada awalnya, penelitian mengenai keefektifan pembelajar dipersepsikan sebagai akibat dari sifat-sifat kepribadian tertentu atau karakteristik yang dimiliki oleh pembelajar. Oleh karena itu, penelitian yang diselenggarakan adalah berusaha menemu kenali sifatfisat atau karakteristik tersebut. Selanjutnya, keefektifan dipandang tidak sebagai fungsi dari karakteristik pembelajar, melainkan metode yang digunakan. Menurut pandangan ini, apa yang sangat menentukan dalam proses pembelajaran adalah metode yang digunakan oleh pembelajarannya. Oleh karena itu penelitian-penelitian pun dipusatkan perhatiannya pada metode pembelajaran. Tahapan berikutnya adalah keefektifan dinilai bergantung pada suasana yang 
diciptakan oleh pembelajar dan dipelihara oleh pembelajar. Oleh karena itu, penelitian pun dipusatkan perhatiannya pada hubungan suasana pembelajaran yang diciptakan oleh pembelajar dengan ptestasi belajar mahasiswa. Bahkan, Charles Hoole memberikan penekanan bahwa keefektifan tenaga pendidik dapat dinilai berdasarkan kreiteria management (Travers, 1981: 14). Tersirat bahwa apabila lembaga pendidikan dikelola secara benar, maka mahasiswa memiliki peluang penuh untuk belajar. Apabila pengelola kelas meberikan kondisi yang diharapkan (favorable conditions) untuk belajar, maka mahasiswa akan belajar. Dan apabila mahasiswa tidak belajar, maka konsisi yang diciptakan oleh pembelajar harus dicela. Mahasiswa tidak dapat dituduh karena gagal belajar, sebab anggapan dasarnya adalah bahwa kegagalan merupakan akibat atau hasil dari kondisi belajar yang tidak memadai (Travers, 1981: 15-17). Lebih belakangan, keefektifan telah dipandang sebagai penguasaan seperangkat kemampuan, dan akhirnya penekanan yang lebih diberikan pada kemampuan untuk menyebarkan (to deploy) kemampuan tersebut secara memadai, yaitu melalui apa yang disebut sebagai pembuatan keputusan profesional (Medley, 1978: 12). Pada tahun 1896, Kratz mengetengahkan hasil penelitiannya mengenai karakteristik tenaga pendidik terbaik sebagaimana dikenali oleh peserta didiknya (Medley, 1978:

12).

\section{MANFAAT DAN TUJUAN}

\subsection{Tujuan Kegiatan}

Tujuan yang ingin dicapai dalam Pengabdian Kepada Masyarakat ini adalah: a. Melakukan pelatihan (workshop) tentang metode pembelajaran berbasis internet bagi guru-guru di Yayasan Mujahidin Kabupaten Malang. b. Diseminasi alat dan metode pembelajaran berbasis internet. Tujuan diseminasi ini adalah untuk memperoleh masukan dalam upaya penyempurnaan pengembangan alat dan metode pembelajaran berbasis internet sebelum benar-benar digunakan di lingkungan Yayasan Mujahidin Kabupaten Malang. c. Menjalani hubungan yang lebih erat antara Politeknik dengan Yayasan Mujahidin Kabupaten Malang

\subsection{Manfaat Kegiatan}

Manfaat kegiatan ini adalah agar para pengajar (ustad) di Yayasan Mujahidin agar dapat:

- Menerapkan model pembelajaran berbasis komputer - Meningkatkan kompetensi pengajaran para guru di Yayasan

Mujahidin

- Meningkatkan efektifitas dan efisiensi dalam mengajar

- Memperbanyak media pembelajaran untuk mendukung keberhasilan pengajaran di Yayasan Mujahidin

\subsection{Pelaksanaan}

Pelatihan ini diikuti sebanyak 15 orang guru Yayasan Mujahidin Kabupaten Malang. Dalam pelatihan secara umum diberikan dua materi utama, yaitu pengetahuan tentang metode pembelajaran dan penggunaan internet untuk pembelajaran. Untuk materi pertama, metode pembelajaran perlu disampaikan, mengingat pada penjajagan awal diketahui bahwa semua peserta sudah memahami namun belum memenuhi kriteria mengajar yang variatif. Mereka sudah dapat mendemonstrasikan cara mengajar yang telah dilakukan selama ini.Sedangkan materi kedua berupa pemanfaatan jaringan internet untuk pembelajaran.. Setelah mengadakan pengabdian kepada masyarakat, maka dalam melihat keberhasilannya harus dilihat dari hasil kegiatan tersebut. Saat ini memang harus diakui hasilnya belum begitu nampak. Tetapi berdasarkan hasil pengamatan selama ini tanda-tanda kearah itu sudah mulai ada. Dengan adanya tingkat pengalaman bekerja yang hampir sama, maka dalam menyerap materi yang diajarkan hasilnya masih dapat dikatakan dapat terserap secara merata. Jadi secara umum dapat dikatakan secara keseluruhan materi yang diberikan dapat dimengerti oleh mereka. Seperti telah disebutkan sebelumnya peserta pengabdian masyarakat ini para yang mempunyai cukup pengalaman dan memiliki keinginan cukup besar untuk menambah pengetahuannya sehingga semakin mendorong keberhasilan pengabdian ini. Dengan pengabdian ini diharapkan para guru Yayasan Mujahidin Kabupaten Malang ini mampu meningkatkan penguasaan metode pembelajaran untuk mengelola proses pengajarannya dan meningkatkan efektifitas dan efisien dalam pengelolaan pembelajaran di era global Keberhasilan pengabdian pada masyarakat ini belum dapat dilihat secara langsung, hal ini akan terlihat dalam peningkatan administrasi kepada masyarakat di masa yang akan dating. Namun jika dilihat dari hasil yang dicapai maka manfaatnya adalah dengan bertambahnya pengetahuan dan wawasan yaitu dengan telah mendapat pengetahuan dan ketrampilan tentang pemanfaatan internet untuk pembelajaran yang benar dalam memberikan pelayanan kepada murid, sehingga diharapkan dengan adanya tambahan pengetahuan ini dapat membantu mereka dalam mengatasi berbagai masalah pembelajaran.

\section{HASIL DAN PEMBAHASAN}

\subsection{Faktor Penghambat}

Pelaksanaan kegiatan pengabdian pada masyarakat ini dirasa tidak ada faktor penghambat yang serius. Hal ini mengingat bahwa para peserta adalah guru Yayasan Mujahidin Kabupaten Malang yang sudah cukup pengalaman dan mereka memang membutuhkan materi yang disampaikan. Selain itu sebelumnya telah terjadi komunikasi yang baik antara KetuaYayasan Mujahidin Kabupaten Malang dengan penyelenggara kegiatan PKM.

\subsection{Faktor Pendorong}

Dengan terselenggaranya pengabdian pada masyarakat ini dirasakan ada beberapa faktor 
pendorong yang menjadikan kegiatan ini dapat dilaksanakan dengan lancar, yaitu: - Minat dan semangat para peserta dalam mengikuti pelatihan sangat besar, sehingga mempermudah dalam proses belajar mengajar dan pemberian motivasi meskipun dalam kondisi yang sederhana. - Para guru Yayasan Mujahidin Kabupaten Malang mempunyai tekad besar untuk mencapai kemajuan sehingga dapat mendorong terlaksananya aktivitas pengabdian pada masyarakat ini. - Pengajar yang selalu siap dengan materi dan alat bantu pengajarannya sehingga memperlancar pelaksanaan

kegiatan.

\section{KESIMPULAN DAN SARAN}

\subsection{Kesimpulan}

Setelah selesainya kegiatan pengabdian pada masyarakat maka hasilnya dapat dievaluasi sebagai berikut

1. Relevansi Kegiatan ini sangat relevan diberikan kepada para guru di Yayasan Mujahidin Kabupaten Malang. Mengingat mereka harus meng-update pengetahuan mereka dengan perkembangan ilmu pendidkan dan pembelajaran agar tidak tertinggal dalam pengelolaan pembelajaran di kelas. 2. Akseptabilitas Materi Pengabdian Kepada Masyarakat yang diberikan mudah diterima dan dimengerti oleh peserta, karena materinya bersifat praktis.

3. Efektifitas Pengabdian ini efektif mencapai tujuannya terutama bagi mereka yang mempunyai daya kreativitas yang tinggi. 4. Ketepatan Ketrampilan yang diberikan sangat tepat sekali, karena mudah dipelajari dan berguna sebagai bekal di masa mendatang. 5. Kegunaan Materi ini sangat berguna untuk mengantisipasi kondisi di masa mendatang, yang berhubungan dengan mengembangkan tugas pokok mereka sebagai pendidik. 6. Pengaruh jangka panjang Akan membawa kemajuan di lingkungannya dalam rangka mensukseskan pembelajaran berbasis IT. 7. Daya ulang dan kreativitas Untuk dapat menerapkan metode pembelajaran ini dengan lancar dan baik, harus selalu diadakan latihan yang serius dan kontinyu agar bekal ketrampilan yang telah diberikan terus berkembang. Kesimpulan Kegiatan pengabdian pada masyarakat telah selesai dilaksanakan dan dapat diambil beberapa kesimpulan yaitu : - Pengabdian ini adalah merupakan kegiatan untuk memperoleh tambahan keterampilan dan pengetahuan serta aplikasi dalam rangka meningkatkan efisiensi dan efektivitas pembelajaran di kelas. - Motivasi peserta sangat tinggi, hal ini terlihat dari antusiasnya peserta mengikuti sampai akhir program. - Hasil pengamatan selama proses kegiatan ini berlangsung maka dapat dilihat bahwa rata-rata penerimaan materi yang disampaikan oleh instruktur cukup baik.

- Untuk lebih meningkatkan ketrampilan yang telah diperoleh maka perlu kiranya para peserta untuk lebih banyak berlatih dan mulai menerapkan dalam proses pembelajaran

$\mathrm{di}$

kelasnya.

\subsection{Saran}

* Agar pengetahuan, ketrampilan dan aplikasi yang telah diberikan tidak hilang, maka perlu kiranya bagi Ketua Yayasan Mujahidin Kabupaten Malang untuk memotivasi para gurunya agar dapat berlatih dan mulai menerapkan dalam proses pembelajaran berbasis internet.

* Untuk lebih banyak memperdalam dan memperoleh keterampilan yang mendukung kemajuan proses pembelajaran di sekolah Yayasan Mujahidin maka perlu kiranya ditingkatkan kerja sama dengan Politeknik Negeri Malang, khususnya sehubungan dengan kegiatan pengabdian pada masyarakat.

* Dengan selesainya kegiatan pengabdian pada masyarakat ini diharapkan agar lebih mempererat hubungan dan kerja sama antara Yayasan Mujahidin Kabupaten Malang dengan Politeknik Negeri Malang.

\section{DAFTAR PUSTAKA}

[1]. Maskan, Mohammad; Hadi,Mustofa \& Kusbianto, Deddy, 2009, Pengembangan Model Pembelajaran Pemasaran Internasional, DP2M Dikti, Depdikbud, Jakarta

[2]. Oetomo, Budi S. Dharma, 2002, eEducation: Konsep, Teknologi dan Aplikasi Internet Pendidikan, Andi Ofse, Yogyakarta

[3]. Patmanthara, Syaad, 2004, Pembelajaran Berbantuan Komputer Sebagai Manfaat Media Pembelajaran, Jurnal Teknologi Elektro dan Kejuruan, Oktober, 2004

[4]. Purbo, Onno W., 2002, Teknologi eLearning Berbasis PHP dan MySQL: Merencanakan dan Mengimplementasikan Sistem eLearning, Jakarta: Gramedia.

[5]. Raharjo, Budi, 2001, Pergolakan Informasi di Indonesia akan Siaran?, Artikel Majalah Tempo, Jakarta: November 2001 